UNIO - EU Law Journal. Vol. 5, No. 1, January 2019, pp 92-108.

®2019 Centre of Studies in European Union Law

School of Law - University of Minho

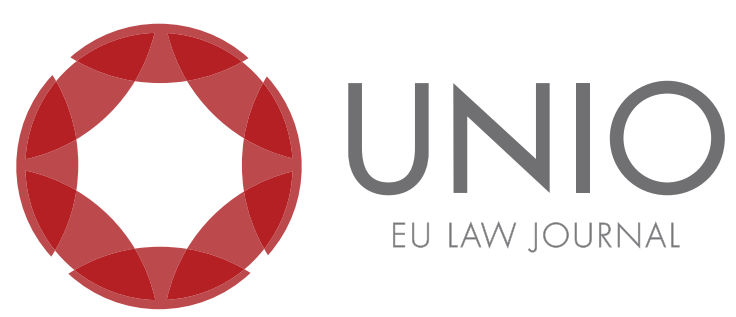

\title{
An overview of the developments of the European Common Fisheries Policy regarding sustainable development and its regionalisation in Portugal and the Autonomous Regions
}

\author{
Rui Castro Vieira*
}

ABSTRACT: The European integration is not only a continental, but also a maritime integration, with the development of a maritime market including its maritime resources like fisheries. The development of the Common Fisheries Policy, in the European Union, has been marked by a few peculiar principles and tension among Member States. These developments have also been challenged by the developments of International Law, especially the Law of the Seas Convention, as well as the increasing attention given to a sustainable development and the need for maritime environmental development. The latest years have also been marked by a need for decentralization and regionalisation of the Common Fisheries Policy. The Iberian nations, especially Portugal, are a distinctive case with the rather difficult Common Fisheries Policy Integration. In spite of that, its singularity regarding its maritime presence and autonomic decentralized model give new potential for a new management and development of a decentralized Common Fisheries Policy, as well as a new possibility for sustainable development. In this paper, we analyse the development of the European Common Fisheries Policy as well as its role and interaction with International Law and the new concerns regarding sustainability of fishing stocks and its new management approach and needs for regionalisation. We also analyse its repercussions on Portugal and the potential offered by its own maritime and territorial peculiarities with its archipelagos and their own qualities and aptitude for a sustainable integration of the Common Fisheries Policy.

KEYWORDS: Common Fisheries Policy - Economic Exclusive Zone - Law of the Seas Convention - sustainable development - Autonomous Regions.

\footnotetext{
* Master's student in EU law at the University of Minho.
} 


\section{I.The Development of the European Common Fisheries Policy}

\section{The European Union and its maritime potential and resources}

The European Union's increasing number of Member-States since the 1970s lead to not only an increased amount of continental land territory, but also to a broader maritime presence, especially in the Atlantic Ocean. Most of the earlier Member-States that integrated the European Project are, historically, former colonial empires with transoceanic aspirations and maritime possessions.

The global geopolitical changes, in the second half of the $20^{\text {th }}$ century, lead to most of these Member-States abandoning their imperial pretensions. ${ }^{1}$ However, the results of centuries of colonialism and maritime expansion still have their presence on the Member-State territories in the European Union with disperse territories that are amassed by some countries.

The European Union presence goes beyond Continental Europe itself with the vast number of archipelagos, islands and territories throughout the world, which ends up leading to special statuses and different applications of European Union law. ${ }^{2}$

The increasing number of Member States in Eastern Europe gave a geopolitical change to the European project with the expansion of its maritime territory and projection back to Continental Europe and the North and Baltic Sea. ${ }^{3}$ Albeit the older Member States being faced to the Atlantic Ocean with Coastal Member States like France, Ireland, Spain and Portugal. With the Iberian archipelagos possessing an economic exclusive zone of 248,084 square kilometres in the Canary archipelago, 426,000 kilometres in the Madeira archipelago and 938,000 kilometres in the Azores archipelago, ${ }^{4}$ extending the maritime jurisdiction of these Member-States, as well as the Maritime Power of the European Union towards the far-reaches of the Atlantic Ocean.

With a coastline of over 65,000 kilometres, the offshore marine area of all the Member-States, encompassing territorial seas, exclusive economic zones and their continental shelves, is larger than all the land territory in the European Union. ${ }^{5}$

Such an extended maritime territory and coastal Member-States in the Union led to the development of maritime economic activities with the use of the resources

\footnotetext{
${ }^{1}$ See Giuliani Garavini, After Empires: European Integration, Decolonization, \& The Challenge from the Global South 1957-1986 (Oxford: Oxford University Press, 2012), 46-59.

${ }^{2}$ Insular regions and territories have special statuses and a special treatment by the Treaty on the Functioning of the European Union, due to their geographical and socioeconomical limitations. See Dimitry Kochenov, "The Application of EU law in the EU's Overseas Regions, Countries, and Territories After the Entry Into Force of The Treaty of Lisbon," Michigan State International Law Review, 20 (2012): 669-704. Jacques Ziller, “L’Union européenne et l'outre-mer," Pouvoirs n. 113 (2005): 125-129. Rui Vieira, "Insular Regionalism and its presence on the European federative model: island regions and their autonomic role and challenges on the European construction," UNIO-EU law Journal, The Official Blog, March 26, 2018 https://officialblogofunio.com/2018/03/26/ insular-regionalism-and-its-presence-on-the-european-federative-model-island-regions-and-theirautonomic-role-and-challenges-on-the-european-construction/\#more-2468.

${ }^{3}$ See Juan Luis Suárez de Vivero and Juan Carlos Rodríguez Mateo, "Maritime EU enlargement. A Geopolitical Perspective," Marine Policy, vol. 30, issue 2 (2006): 167.

${ }^{4}$ See Juan Luis Suárez de Vivero and Juan Carlos Rodríguez Mateo, "Atlas of the European Seas and Oceans: Marine Jurisdictions, Sea uses and Governance", http://www.marineplan.es/ES/ATLAS_ EUROPA.pdf.

${ }^{5}$ See Lawrence Juda, "The European Union and Ocean Use Management: The Marine Strategy and the Maritime Policy,” Ocean Development \& International Law, vol. 38, issue 3 (2007): 260.
} 
provided by the Ocean. However, in some cases, maritime resources are scarce natural resources that end up leading to debates, considering the need for allocation. Fisheries are a strong example of this, and the European Union is the world's second largest fishing power after China. ${ }^{6}$

Marine and maritime resources employ more than five million people throughout the European coast and waters, creating a gross added value in excess of five hundred billion euros. ${ }^{7}$ Maritime resources and fisheries are, therefore, an important element for the european economy and common market. European integration is also a maritime integration, with the bonding effect of Member State economies and the removal of needless and dilatory bureaucracies that affected fishing activities in other Member States maritime zones. ${ }^{8}$

\section{The early developments of the Common Fishery Policy, the equal access principle, and the repercussions of the paradigm shift of the Hague Resolution}

The original 1957 Treaty of Rome was vague concerning fisheries with Article 38 stating that fisheries and products of first stage processing related to them were an extension of the Common Market, ${ }^{9}$ even though most the founding Member States were Atlantic States, with Luxembourg being the only landlocked State. ${ }^{10}$ Fisheries seemed to be associated with the agriculture due to the fact they were a primary sector, although this is unclear. The same provisions that authorized a Common Agricultural Policy also authorised a Common Fisheries Policy, despite the peculiar differences with the resources.

The first steps towards the development of fisheries management and fishing rights were taken through international conventions, like the European Fisheries Convention of 1964, which defined that the signatory countries were able to limit access to waters up to twelve nautical miles of their coastal base lines. ${ }^{11}$ It was also established that sovereignty of coastal states would span six nautical miles from the shore baseline. The States, therefore, had the exclusive right to fish in that area and ownership of fishing rights in territorial seas spanning up to twelve nautical miles. ${ }^{12}$

Despite that, Member States like France demanded a Common Market Organisation for fisheries products. The council negotiations for a Common Fisheries Policy was marked by conflictive positions between Southern and Central European States. France and Italy demanded a structural policy that would use community funding to help develop infrastructure as well as a common market organisation supporting price levels and securing income for producers. Germany and the Netherlands, on the

\footnotetext{
${ }^{6}$ See Tiffany Walter, "The EU's Common Fisheries Policy: A Review and Assessment", http://aei. pitt.edu/29777/1/WalterFisheries2010EUMAedi.pdf

${ }^{7}$ See Davor Mance, Borna Debelic and Sinisa Vilke, "Integrated Maritime Policy of the European Union as the Planning Model for Croatia," Pomorski Zbornik, vol. 49-50, n. 1 (2015): 29.

${ }^{8}$ See João Coimbra de Oliveira, "O pescador e o seu duplo: migrações transnacionais no mar europeu," Etnográfica Revista do Centro em Rede de Investigação em Antropologia, vol. 15, n. 3 (2011): 452.

9 See David Symes, “The European Community's Common Fisheries Policy," Ocean \& Coastal Management, vol. 35 (1997): 140.

${ }^{10}$ See Suárez de Vivero and Rodríguez Mateo, "Maritime EU enlargement”...,168.

${ }^{11}$ See Lukas Schweiger, "The Evolution of the Common Fisheries Policy: Governance of a CommonPool Resource in the Context of European Integration,” Working Paper No. 07/2010 (2010): 13.

${ }^{12}$ See Tiffany Walter, “The EU’s Common Fisheries Policy: A Review and Assessment”, http://aei. pitt.edu/29777/1/WalterFisheries2010EUMAedi.pdf
} 
other hand, had a more liberal approach and were opposed to these demands. ${ }^{13}$

This led to the Common Fisheries Policy being marked by a slow development in the next decades. The lack of inclusion of Fisheries in the original Treaties lead to the first developments to start only in the 1970s. ${ }^{14}$ The first major step being in 1970 with Regulation No. 2141/70 of the Council of 20 October 1970 which laid down a common structural policy for the fishing industry and Regulation No. 2142/70 of the Council of 20 October, which defined the common organisation of the market in fishery products. These Regulations developed with the development of the Common Market. These Regulations laid down the first two of the four pillars of the Common Fisheries Policy, Structural Policy and Common Market Organisation. ${ }^{15}$

The anticipation of the entrance of Denmark, Ireland, the United Kingdom and Greece into the European Community, with the newer Member States having a strong interest in fishing and abundant coastal resources, were also a major influence in the establishment of these regulations and the first developments of a fisheries management.

These Regulations did not have any detailed provisions concerning structural development, but it established a few principles to all new Member States, like the principle of non-discrimination, already established in the Treaty of Rome, which was translated into Regulation 2141/70 as "equal access" into the Preamble. ${ }^{16}$ It was logical to eliminate forms of discriminations preventing the free movement of fish boats, considering that the Treaty of Rome promoted the removal of barriers to fish trade. ${ }^{17}$

The said Regulation lead to the consideration of fisheries as common resources with the need, by the part of the Community, back then, to adopt measures to safeguard the stocks of fish present in the waters. The aim of the Member States co-coordination being the harmonious and balanced development of the fishing industry within the general economy, in accordance with Article 1 of the Regulation. Article 10 defined specific measures for these aims which involved the restructuration of fishing fleets and other means of production, adaptation of production and marketing conditions to market requirements and the improvement, in step with technical progress, of the standard and conditions of living of the population which depends on fishing for its livelihood.

The equal access principle was defined in Article 2(1) of the mentioned Regulation, stating that "Rules applied by each Member State in respect of fishing in the maritime waters coming under its sovereignty or within its jurisdiction shall not lead to differences in treatment of other Member States. Member States shall ensure in particular equal conditions of access to and use of the fishing

\footnotetext{
${ }^{13}$ See Schweiger, "The Evolution of the Common Fisheries Policy: Governance of a Common-Pool Resource in the Context of"..., 15.

${ }^{14}$ See Francisco Pereira Coutinho, "Federalismo e constitucionalismo na União Europeia: a delimitação vertical e horizontal de competências nos domínios das pescas," In La Gobernanza De Los Mares Y Oceanos Nuvevas Realidades, Nuevos Desafíos: A Governação dos Mares e Oceanos Novas Realidades, Novos Desafios, dirs. Jorge Pueyo Losa e Wladimir Brito, coords. Maria Teresa Ponte Iglesias and Maria da Assunção do Vale Pereira, (Santiago de Compostela: Andavira, 2012), 478.

15 The Common Fisheries Policy is divided into four structural pillars: structural policy, common organization of the market, fisheries agreements with third countries and resource conservation and management system. For a deeper understanding, see Eugénia da Conceição-Heldt, The Common Fisheries Policy In The European Union: A study in Integrative and Distributive Bargaining (London: Routledge, 2004), 17-19.

${ }^{16}$ See Symes, “The European Community's Common Fisheries Policy”..., 140-141.

${ }^{17}$ See Koen Van den Bosche, "EU Enlargements And Fisheries: A Legal Analysis Steps Towards The Re-Nationalisation of EU Maritime Waters," Jurisprudencija t.72/64 (2005): 128.
} 
grounds situated in the waters referred to in the preceding subparagraph for all fishing vessels fying the flag of a Member State and registered in Community territory".

That meant that there shall be no discrimination between nationals of Member States on the grounds of nationality. Which, in this case, meant the access of all Member State' vessels to other Member State's waters, ensuring, therefore, an equal access to the fishing grounds of each Member-State. ${ }^{18}$ This did not mean an unrestricted, completely open access to the Community's waters. However, any regulation within the Member States' fishing zones should not restrict fishermen because of their nationality.

This equal access principle also implied the abrogation of the guarantee of national sovereignty within the six and twelve mile territorial limits, previously established in 1964, which created some tension and controversies between Member States, to the point of being a threat to the Common Fisheries Policy. The fact that Norway did not become a Member of the European Community because of the problems associated with fisheries is, possibly, the main example of the hardships with the negotiations concerning the adaptation of the Common Fisheries Policy to the newer Member States, considering the applicant Member States possessed greater fisheries resources and, therefore, had different interests. ${ }^{19}$

The 1972 Treaty of Accession, in its $100^{\text {th }}$ Article, however lulled this tension by allowing Member States "to restrict fishing in waters under their sovereignty or jurisdiction, situated within a limit of six nautical miles, calculated from the base lines of the coastal Member State, to vessels which fish traditionally in those waters and which operate from ports in that geographical coastal area" until 31 December 1982. This allowed, therefore, a ten year derogation of the equal access principle up to six miles from the Member State's base lines of coast.

Article 101 of the Treaty of Accession also defined an extension of the same six to twelve miles for areas especially dependent on fisheries, leading to a temporary suspension of the equal access principle. ${ }^{20}$

During this dormant period, however, there was a major improvement with the agreement of the creation of a 200-mile economic exclusive zone, allowing the sovereign rights of access and exploration.

Iceland, in 1973, declared the zone up to 200 miles from its coast to be under its authority. British fishers started to increasingly fish more around the open seas surrounding Iceland that lead to some tension between the States. That led to the Resolution of 3 November of 1976 on certain aspects of the creation of a 200-mile fishing zone in the Community, on what was known as The Hague Resolution. This confidential Communication from the Commission to the Council ${ }^{21}$ expressed the awareness of the Commission of the International Context in which fishing takes place, suggesting that Member States act in concert to extend their fishing limits to 200 miles from 1 January 1977 in the North Sea and North Atlantic.

Annex 6 of this Resolution matched the demands of the United Kingdom and Ireland, stating that "If no agreement is reached for 1977 within the international fisheries

\footnotetext{
${ }^{18}$ See Robin Churchill and Daniel Owen, The EC Common Fisheries Policy (New York: Oxford University Press, 2010), 197. R. Simonnet, "Competences of The European Economic Community in the Field of Fisheries", in Management of World Fisheries: Implications of Extended Coastal State Jurisdiction, ed. Edward L. Miles (Seattle: University of Washington Press, 1989), 116.

${ }^{19}$ See Astrid Berg, Implementing and Enforcing European Fisheries Law: The implementation of the Common Fisheries Policy in The Netherlands and in the United Kingdom (The Hague: Kluwer Law International, 1999), 23.

${ }^{20}$ See Symes, "The European Community's Common Fisheries Policy”...141.

${ }^{21} \operatorname{COM}(76) / 500 /$ Final of 23 September of 1976, Brussels, also known as The Hague Resolution, was only published in 1981.
} 
Commission and subsequently no autonomous Community measures could be adopted immediately, the Member States could then adopt, as an interim measure and in form which avoids discrimination appropriate measures to ensure the protection of resources situated in the fishing zones off their coasts".

This period was a chaotic period in the shaping of a Common Policy, with the extended Economic Exclusive Zone and the depletion of Fishing Stocks putting some pressure on the European Community with the Common Fisheries Policy not matching extended zones. This led to conservation measures being taken by the European Community with the definition of catch rates, that were referred as Total Allowable Catch. These catch rates were proposed by the Commission every year, between 1978 and 1982, although they were only adopted in 1980. After all, it was known, based on stock assessment models completed at the time, that there was a need to be some sort of catch limit for fishermen, this quota system was the most efficient way to allocate numbers. This Total Allowable Catch policy was at debate, alongside the equal access principle, throughout the 1976 definition of the Common Fisheries Policy. ${ }^{22}$ Despite that, this first attempt of introducing a management system to determine the total allowable catches failed, considering the lack of agreement on the conservation and management policy. ${ }^{23}$

Negotiations lasted from 1976 until 1983, with the adoption, in 1982, of the United Nations Convention on the Law of the Sea. ${ }^{24}$

The Accession of Portugal and Spain, in 1986, lead to the development of the last pillar of the Common Fisheries Policy, the conservation and the management policy for fish resources. ${ }^{25}$

During this period, the Common Fisheries Policy, however, developed with Regulations 100/76 of 19 January of 1976, on the common organization of the market in fishery products and Regulation 101/76, of 19 January of 1976 that laid down a common structural policy for the fishing industry. These Regulations readapted the policy with Article 4 of Regulation 100/76 showing concerns with over-fishing, allowing the Council to determine necessary conservation measures.

\section{The creation of the Common Fishery Policy and its conservation, the issue with fishing stocks}

However, as it was previously mentioned, the global changes came in 1983 with the creation of the Economic Exclusive Zone. The Hague Resolution had already encouraged European States to extend the limits of their fishing zones, leading to a

\footnotetext{
${ }^{22}$ See Schweiger, "The Evolution of the Common Fisheries Policy: Governance of a Common-Pool Resource in the Context of"... 24-27 and Walter, "The EU's Common Fisheries Policy: A Review and"...

${ }^{23}$ See Eugénia da Conceição-Heldt, The Common Fisheries Policy in the European Union: A Study in Integrative and Distributive Bargaining (London: Routledge, 2004), 20.

${ }^{24}$ The Convention contains the articles on legal regime of the Exclusive Economic Zone; the limitation of the Zone, the sovereign rights of the coastal state to manage the zone in good faith; the regard for the economic interests of the third states; regulations of the certain activities in the zone, such as marine scientific research, protection and preservation of the marine environment, and the establishment and use of artificial islands; freedom of navigation and over flight; the freedom to lay submarine cables and pipelines; military and strategic use of zone; and the means of settlement of disputes. For a deeper understanding See MOM Ravin, "Law of the Sea: Maritime Boundaries and Dispute Settlement Mechanisms", http://www.un.org/depts/los/nippon/unnff_programme_ home/fellows_pages/fellows_papers/mom_0506_cambodia.pdf.

${ }^{25}$ See Conceição-Heldt, The Common Fisheries Policy in the European Union... 20.
} 
necessary major reform of the Common Fisheries Policy. ${ }^{26}$ That lead to the creation of Regulation 170/83 that established a Community System for the conservation and management of fishery resources. ${ }^{27}$

This Regulation lead to the definitive creation of a comprehensive European Common Fisheries Policy, which established a common agreed conservation policy. The Community was given the formal competence to govern the conservation policy by determining the yearly annual Total Allowable Catches for the Member States, securing the sharing of resources based on the concept of relative stability that gives each Member-State a constant relative share of the quotas. ${ }^{28}$ This principle of relative stability, although already developed like the first Total Allowable Catches in the long and hectic negotiations period between 1976 and 1983, was only applied with the 1983 Regulation. ${ }^{29}$

These Total Allowable Catches and the Quota System were the core of the conservation and management Policy alongside other associated technical measures like the minimum mesh and fish sizes and closed seasons. ${ }^{30}$

Article 3 of the Regulation established the annual Total Allowable Catches, with Article 4 defining the distribution between the Member States to be "in a manner which assures each Member State relative stability of fishing activities for each of the stocks considered". This distribution had to take into consideration the relative stability principle.

This relative stability principle defined the allocation of national quotas between Member-States in accordance with their fishing preferences and catches, certain preferences applicable to certain fishermen and regions, defined in The Hague Resolution and the consideration for the losses suffered by Member States' fishing vessels in third countries after the introduction of the 200-mile Economic Exclusive Zone.

Article 5, however, allowed Member-States to exchange fishing quotas, as long as the Commission was informed about it.

The Scientific and Technical Committee for Fisheries, that was set up by Article 12 had a major role instituting these fishing catch limits, which would have to be estimated in light of the available scientific advice. ${ }^{31}$

This relative stability principle contrasted with the equal access principle and changed the modus operandi of the Common Fisheries Policy. The criteria in the relative stability principle also caused some inequalities among Member States. ${ }^{32}$ The Commission first based the numbers of the Total Allowable Catches on scientific data from the International Council for the exploration of the Sea and the Scientific and Technical Committee of the Commission. In the beginning, it closely followed the recommendations of the said Council, in what could be called an inflexible conservationist approach, moving away from the recommendations in its later proposals with the negotiations being done by Member States and the Total Allowable

\footnotetext{
${ }^{26}$ See Van den Bosche, "EU Enlargements And Fisheries: A Legal Analysis Steps Towards The ReNationalisation of"... 129.

${ }^{27}$ See Symes, “The European Community’s Common Fisheries Policy”... 142-143.

${ }^{28}$ See Carster Lynge Jensen, "A Critical Review of the Common Fisheries Policy," Department of Environmental and Business Economics, University of Southern Denmark Working Paper n. 6 (1999): 24-25.

${ }^{29}$ See A Politica Económica da Pesca: Guia do Utilizador (Belgium: European Community, 2009), 6.

${ }^{30}$ See Conceição-Heldt, The Common Fisheries Policy in the European Union...68.

${ }^{31}$ See A Karagiannakos, "Total Allowable Catch (TAC) and quota management system in the European Union,” Marine Policy, vol. 20, issue 3 (1996): 235-236.

${ }^{32}$ See Symes, “The European Community's Common Fisheries Policy”... 143.
} 
Catches ended up exceeding the biological recommendations. ${ }^{33}$

The policy transfer to the supranational level did not manage to solve the problems of resources scarcity and the catch quota system is criticisable for being difficult to implement properly.

This system was adopted by the Commission, taking into account Article 61 of the Law of the Sea Convention ${ }^{34}$ that stated that coastal States shall determine their Total Allowable Catches of the living resources in their economic exclusive zone. It was also a beneficial system for the European integration process, considering it would imply a common management of fishery resources. ${ }^{35}$ After all, federalism is part of the European project's core, in the form of a federative network with supranational, national and subnational political actors. These political actors are under a duty of sincere cooperation and its correspondent principle of loyalty, binding the Member States to common responsibilities, in this sense, a common management of resources is part of the dynamic federative process of the European construction, as well as many other political entities, considering that most of the world's population is living in countries with some form of federative commitment. ${ }^{36}$

In any case, despite the early efforts, the application of such a principle could not be mathematically precise, especially in a political, economic and technological dynamic space like the European Union. Events like the Accession of Spain and Portugal and the reunification of Germany only challenged this principle. The possibility of a new "Spanish Armada" invading northern waters only lead to Member States restraining, even more, the equal access principle, considering that the waters around the Iberian States and their respective archipelagos were comparatively poor. ${ }^{37}$

The fishing industry has always been a competitive sector, after all, and such quotas were not easy to articulate and the competitive number of Member States with their own maritime interests lead to some decisions regarding fishing quotas to be more political than scientific. ${ }^{38}$

\footnotetext{
${ }^{33}$ See Schweiger, "The Evolution of the Common Fisheries Policy: Governance of a Common-Pool Resource in the Context of"... 41-47.

${ }^{34}$ The Law of the Sea Convention promotes regional and sub-regional forms of cooperation, for a deeper understanding see Fernando José Correia Cardoso, “A Convenção Das Nações Unidas Sobre o Direito Do Mar No Contexto Da Conferência Das Nações Unidas Sobre o Desenvolvimento Sustentável. Reflexão Sobre Algumas Questões De Natureza Jurídica," Revista da Faculdade De Direito da Universidade do Porto, vol. XI (2014): 58-62.

${ }^{35}$ See Conceição-Heldt, The Common Fisheries Policy in the European Union... 19, 67-68.

${ }^{36}$ See Dimitry Kochenov, "On the Tiles and Pillars: EU Citizenship as a Federal Denomination," in EU Citizenship and Federalism: The Role of Rights, ed. Dimitry Kochenov (Cambridge: Cambridge University Press, 2017), 16-18. Alessandra Silveira, "Interconstitucionalidade: normas constitucionais em rede e integração europeia na sociedade mundial," in Interconstitucionalidade e Interdisciplinariedade: Desafios, âmbitos e niveis de interação no mundo global, coord. Alexandre Walmott Borges, Saulo de Oliveira Pinto Coelho (Uberlândia MG: LAECC, 2015), 45-53. Alessandra Silveira, Princípios de Direito da União Europeia: Doutrina e Jurisprudência (Lisbon, Quid Iuris, 2011), 103-104. Matj Acceto, "Federalismo," in Enciclopédia da União Europeia, coords. Ana Paula Brandão, Francisco Pereira Coutinho, Joana Covelo Abreu, Isabel Camião (Lisbon: Petrony, 2017), 195-196. Rui Vieira, "Insular Regionalism and its presence on the European federative model: island regions"...

${ }^{37}$ See Karagiannakos, "Total Allowable Catch (TAC) and quota management system in the"... 236. Van den Bosche, "EU Enlargements And Fisheries: A Legal Analysis Steps Towards The ReNationalisation of”... 130. Symes, “The European Community's Common Fisheries Policy”... 144. ${ }^{38}$ See Abel Laureano and Altina Rento, "Uma sumária radiografia da política comum das pescas da União Europeia," Brą̧ilian Journal of International Law, vol. 9, n. 3 (2012): 78.
} 


\section{The development of environmental concerns surrounding maritime resources and the decentralization of the Common Fisheries Policy}

\section{The Law of the Sea Convention and the pathway to sustainability}

In spite of the flaws in the conservation policies throughout the next years with the Total Allowable Catch quotas being often set higher than what scientifically was advised, with the recommended mesh-size regulations being delayed, not to mention the poor enforcement of the Common Fisheries Policy, leading to serious declines of fishery resources ${ }^{39}$ the participation of European States in the Law of Sea Convention had an impact on the shaping of Conservation policies worldwide, as well as cooperation between States concerning Ocean resources management.

The European Community established its competence concerning this form of management with the European Court of Justice defining these competences on precedents like the AETR case of 1971 that Member States' Treaty-making Competences are removed in areas where the exercise could clash with Internal Community rules, giving therefore, the Competences to the European Community regarding common internal rules and the Common Market that could not be affected by Member States initiatives in an incompatible way.

A similar precedent that applied these principles was the 1976 Kramer case that involved Dutch fishermen infringing certain provisions aimed at ensuring the conservation of stocks in the North-East Atlantic. Those were adopted by the Netherlands, in accordance with the commitments under the North-East Atlantic Fisheries Convention. This Convention defined some fishing quotas and rules that were breached. The Dutch fishermen, however, claimed that the Netherlands were acting against the principled laid on the AETR case. The Court, however, ruled that "the Community not yet having fully exercised its functions in the matter... the Member States had the power to assume commitments". Nonetheless, the Court stated that the Community had implied powers to conclude agreements on this field, considering that, at that time, the first two Regulations (2141/70 and 2142/70) stated the Community policy objectives with respect to fisheries conservation and authorised the Council to adopt the "necessary measures". "The Commission of the European Communities v United Kingdom of Great Britain and Northern Ireland" case, in 1979 also asserted, regarding fisheries policy, that the Member States could only act as trustees for the common interest, having, therefore, to cooperate with the other Member States and Institutions.

In this sense, the Community's application of International Law regarding fisheries had a binding and coordinated application on the Member States that shared co-responsibilities.

An International governance of Oceans and Seas is not easy to establish without an entity with global responsibility, leading to most organizations having to rely on soft law instruments, in any case, the concerns with the sustainability of maritime resources have been increasing throughout the world.

Articles 61-72 established the needs of resources management and cooperation with other States and International Organizations, the conservation criteria associated

\footnotetext{
${ }^{39}$ See Tim Daw and Tim Gray, "Fisheries Science and Sustainability in international policy: a study of failure in the European Union's Common Fisheries Policy," Marine Policy, vol. 29 (2005): 190.
} 
are the use of scientific data, preservation of captured species and the consideration of other national interests. The measures adopted by the European Community derivate from the Law of the Sea Convention, which ensured the conservation policies, especially concerning Economic Exclusive Zones.

The Common Fisheries Policies was reviewed in 1992 with no fundamental changes, with the principle of relative stability prevailing over the equal access principle, giving an increased importance to conservation and to a rational and sustainable exploitation of resources. ${ }^{40}$ The European Community also joined the Law of the Sea Convention in 1998, ${ }^{41}$ with both the Community and the Member States participating in both, a simultaneous and autonomous way, with Article 5(1) of Annex IX of the Convention defining the need for a declaration defining the competences that are shared between the Member States and the Community.

These changes lead to more environmental and sustainability concerns surrounding maritime resources and fisheries management. This concern with sustainability and the environment were already a major international issue with the 1992 Rio Declaration of the Environment. In fact, the 1990s are marked with these international concerns surrounding the environmental and sustainability. The Precautionary principle, elaborated by German doctrine in the 1970s, was reflected on many international agreements and declarations. This principle stated the scientific uncertainty should not be a reason to avoid present measures regarding the prevention of environmental harm and was particularly supported by the Rio declaration. The Food and Agriculture Organization of the United Nations emphasized its practical meaning, especially regarding fisheries. International fishery stocks agreements also kept being developed, like the 1995 FAO Code of Conduct for Responsible Fisheries and its four international plans of action. It is also worth mentioning that the FAO Committee on Fisheries is the only permanent international forum which, periodically and on a world-wide basis, examines major fisheries concerns and provides recommendations to government, regional management bodies and other stakeholders. ${ }^{42}$

There was also, in this period, some dissatisfaction with the poor environmental record of the Common Fisheries Policy, regarding the management of fishing stock and the constant over-fishing in spite of the fishing quotas, leading many academics and environmental non-governmental organizations to voice their concerns with the environmental deficit of the Common Fisheries Policy. This state of affairs gave rise to demand for a more sustainable policy. ${ }^{43}$

Sustainability can be conceived as a structural element of a Constitutional State or even in the European Union's case, its political federative project, although being

\footnotetext{
${ }^{40}$ See Symes, "The European Community's Common Fisheries Policy"... 144-145.

${ }^{41}$ The European Economic Community was given an observer status in 1974, on the Law of the Sea Convention, its participation was with the achievement of what was known as the "EEC clause" in article 305 (1) (f) and Annex IX of the Convention, after some opposition by other States that feared a risk of double representation. This Annex is especially meant for the European Economic Community with its emphasis on conferral competences from the Member-States to the organization. For more on the European participation on the Law of the Sea Convention, see Esa Paasivirta, "The European Union And The United Nations Convention On the Law Of The Sea," Fordham International Law Journal, vol. 38, issue 4 (2015): 1046-1051.

${ }^{42}$ See Olav Schram Stokke and Clare Coffey, "Precaution, ICES and the common fisheries policy: a study of regime interplay," Marine Policy, vol. 28 (2004): 117-118.

${ }^{43}$ See Eloise Todd and Ella Ritchie, "Environmental Non-Governmental Organizations and the Common Fisheries Policy," Aquatic Conservation: Marine and Freshwater Ecosystems, vol. 10, n. 2 (2000): 141-142.
} 
an ambiguous principle that can be interpreted in many ways. From a biological standpoint, this principle focuses on the protection and maintenance of resources, that the consumption of these should not go above their ability to regenerate. However, from a broader view, it means what some doctrine refer to as three pillars, the first being ecological sustainability, the second being economic sustainability and the third being social sustainability. In an international context, this idea is expressed through as a set of political guidelines between States. ${ }^{44}$

This sustainability principle is one of the most complex principles, considering how multidimensional it can be, considering it also emphasizes the need for a planetary consideration, as well as an intergenerational approach to political measures. In this sense, it is associated with an idea of global and intergenerational justice. ${ }^{45}$

Another core principle, as was already mentioned, is the Precautionary principle that is often addressed by the European Institutions, especially with the entrance of the new millennium its application on the Common Fisheries Policy was debated with the Commission stating the need to reduce fish mortality to a safer level and allowing a safety margin. The need to introduce medium-term strategies through effective multiannual approaches was also addressed. ${ }^{46}$

A major reform was implemented in 2002 with Council Regulation 2371/2002 with the objective of ensuring the sustainable exploitation of living aquatic resources. The Precautionary principle was taken into consideration, especially considering Article 2 (1) of the Regulation that states that the Union must apply a precautionary approach in protection and conservation measures. Article 3 defines this precautionary approach as the fact that a lack of scientific evidence does not justify postponing or failing to take conservative and management measures. This precautionary approach also must be taken toward the management of stocks within safe biological limits, in accordance to Article 6(3) of the Regulation.

The Commission's role was also emphasized with Articles 26 and 27 stating that this institution is responsible for the evaluation and control of Member State compliance and with Article 7 allowing it to take, on its own initiative, emergency measures if there is evidence of a serious threat to the conservation of living resources, which would be the case if a Member-State was exceeding their fishing allowance allocated by the Council. ${ }^{47}$

Another main reform was the implementation of multi-annual plans for stocks outside safe biological limits and for other stocks, as far as necessary, the International Council for the Exploration of the Sea had a major role in influencing the Common Fisheries Regime as well as elaborating and translating the precautionary approach in the European Community's context, especially at the end of the 1990s with its advice regarding the use of rebuilding plans for the European hake and code stocks. ${ }^{48}$

\footnotetext{
${ }^{44}$ See José Joaquim Gomes Canotilho, “O Princípio da Sustentabilidade como Princípio estruturante do Direito Constitucional,” Polytechnical Studies Review, vol. VIII, n. 13 (2010): 7-10.

${ }^{45}$ See Alexandra Aragão, "Ambiente," in Direito da União Europeia: Elementos de Direito e Políticas da União, coords. Alessandra Silveira, Mariana Canotilho, Pedro Madeira Froufe (Coimbra, Almedina, 2016), 1097-1098.

${ }^{46}$ See "Communication from the Commission to the Council and the European Parliament - Application of the precautionary principle and multiannual arrangements for setting TACs" COM(2000)/803/final. ${ }^{47}$ See Alexander Proelss and Katherine Houghton, "The EU Common Fisheries Policy in the light of the precautionary principle," Ocean \& Coastal Management, vol. 70 (2012): 25

${ }^{48}$ See Schram Stokke and Coffey, "Precaution, ICES and the common fisheries policy: a study of"... 124.
} 
A fleet tonnage reduction was also implemented, considering the issues with overfishing already previously mentioned. The reforms, in 2002, were mainly focused on granting more responsibility to Member States, as well as an attempt to increase "good governance" principles, an important tool being the creation of Regional Advisory Councils, which govern different areas of European waters and attempt to act as a more efficient pathway to get information from local stakeholders and provide advice for the Commission, focusing on long term sustainability goals. ${ }^{49}$ This creation led to a decentralizing and regionalizing shift of the Common Fisheries Policy, whose responsibilities were too centred on the Commission and European institutions.

\section{The regionalisation of the Common Fisheries Policy}

Throughout the $20^{\text {th }}$ century, there was a constant shift on the political-institutional power with the erosion of the Nation-State concept. In this sense, not only has there been the development of transnational forms of regulations and commitments, but also infranational ones, especially in a post-modern political construction like the European integration.

In the Common Fisheries Policy, this tendency was also noted in the late 1990s, although, as it was noted before, the development through the years of the Common Fisheries Policy, especially with national interests and pressure for some development of a particular sensitiveness for some regions, there were some references about the regionalisation of the fisheries policy during the works of the 1992 review, which were not put into practice. Some studies and reports pressured for some decentralisation of the fisheries policy, with particular support from the United Kingdom. This period, after the Treaty of Maastricht, was peculiar for the arguments between centralist and decentralist policies.

The Common Fisheries Policy had also been, so far, accused of its "topdown management approach" and for having an "interventionist and centralised management". Furthermore, most Member States just did not follow the spirit of a European Community's central level regulation and there was an inconsistency between fishermen and administration on the goals and means of fishery management. Therefore, there was a need to involve the stakeholders in this management and the 2002 review process involved some consultations by the part of the Commission.

Some academic views also consider that this "top-down management" was one of the causes of the Common Fisheries Policy being, throughout the years, "a political success but an environmental failure", with the tendency for hard regulations that often failed. The idea of a greater participation and efficiency, by getting more people involved in the decision-making process and procedures that would end up affecting them, in many sectors was one of the main premises of the notion of decentralisation, which was a vigorous academic discussion in many states. ${ }^{50}$ Even from an environmental standpoint, decentralisation has been seen as beneficial, considering that local institutions have a better knowledge to address some of the issues. ${ }^{51}$ The 1992 Rio declaration on its Principle 10 already stated that the environmental issues are best handled with the

\footnotetext{
${ }^{49}$ See Walter, "The EU's Common Fisheries Policy: A Review and”...

${ }^{50}$ See Søren Q. Eliasen, Troels J. Hegland and Jesper Raakjær, "Decentralising: The implementation of regionalisation and co-management under the post-2013 Common Fisheries Policy," Marine Policy, vol. 62 (2015): 225.

${ }^{51}$ See "Decentralization and environmental issues", on: http://www.fao.org/docrep/005/y4256e/ y4256e05.htm.
} 
participation of all concerned citizens.

The 2002 review lead to a major step with its framework regulation making provisions for the creation of Regional Advisory Councils, covering the 5 regional seas, with broadly based stakeholder representation, their role being to advise the Commission and Member States on fisheries matters, although they were not bound by the advice received from these Councils. Their influence was, therefore, rather limited, but, in any case, the first steps for the regionalisation and decentralisation of the Common Fisheries Policy were taken.

That lead to some developments and dynamism after the 2002 reform, with many other factors like the deteriorating economic conditions in key sectors of the fishing industry, the sense of "unfinished business" with the development of Regional Advisory Councils. Despite the recovery of the key stocks, management of fisheries was becoming increasingly complicated with the layering of regulation.

The first experiences in the Baltic and North Sea, where stakeholder cooperation was strong, proved the usefulness of Regional Advisory Councils and their advice on a wide range of regional issues There was an increasing recognition of their importance in subsequent years, ${ }^{52}$ leading to further developments with Council Decision 2007/409 defining their geographical coverage, structure and procedural rules and Council Decision 2007/409 providing them with the necessary funding aimed at their goals. The Marine Strategy Framework Directive, Directive 2008/56 of 2008, and the Integrated Maritime Policy, created in 2007, focused on enhancing the sustainable development of the European maritime economy, ${ }^{53}$ both acknowledged the need for a robust spatial framework, based on the regional seas, to achieve the necessary objectives. ${ }^{54}$

\section{The Common Fisheries Policy in Portugal and the distinctive case of the Autonomous Regions}

\section{The integration of Portugal on the Common Fisheries Policy}

The complex developments of the Common Fisheries Policy and its environmental and management evolution also met with the challenge of the accession of the Iberian Peninsula in the Community and therefore, met with two major coastal nations and the possibility of an Iberian (mostly Spanish) armada invading the Common Fisheries.

In the Portuguese case, the relationship with the Sea is particularly significant, considering the historical background from the $15^{\text {th }}$ to the $20^{\text {th }}$ century and its maritime presence that is still manifested with the early commitment with NATO regarding oceanic Atlantic security and defence. ${ }^{55}$

Historically, Portugal has always been a nation with a huge maritime spirit and fishing tradition. Being, traditionally, a deeply catholic country, led to it being influenced by the Christian values regarding penitence and eating habits, as well as its hostility to abusive meat consumption, while fish and fishing were associated

\footnotetext{
${ }^{52}$ See David Symes, "Regionalising the Common Fisheries Policy: context, content and controversy", on: https:/ / maritimestudiesjournal.springeropen.com/track/pdf/10.1186/2212-9790-11-6.

${ }^{53}$ See "Progress of the EU's Integrated Maritime Policy- Report from the Commission to the European Parliament, the Council, the European Economic and Social Committee and the Committee of the Regions" $\operatorname{COM}(2012) / 491 /$ final.

${ }^{54}$ See Symes, "Regionalising the Common Fisheries Policy"...

${ }^{55}$ See Adriano Moreira, "Portugal e o Mar," Polis: Revista de Estudos Jurídico-politicos n. 17 (2008): 5-11.
} 
with virtue..$^{56}$

This fishing tradition ended up being a big challenge for the European Community and its recent Common Fisheries Policy. The Accession of Portugal, alongside Spain, in 1986, influenced the 1983 reform, the sheer economic importance to these two coastal states had important consequences for the Common Fisheries Policy, leading to the need to provide special arrangements to the two new Member States, as well as a new structural policy. The fact these two States had big fleets lead to some unwillingness on the part of the other 10 Member States. In any case, they both could oin the Common Fisheries Policy with the Act of Accession having some major restrictions. The access of the vessels of these two Coastal States to the Economic Exclusive Zone of the other Member States was also restricted until 31 December of 2002, with the expiry of Regulation 170/83 and a derogation of the equal access principle. ${ }^{57}$ This 17 -year transition period was particularly long compared to the average duration of transition agreements, which normally last seven to ten years. Both States did an effort to meet up the Common Fisheries Policy Regulations. The Portuguese accession led to a rising of fishing imports and a strengthening of the Portuguese links with its Community partners, in any case, the control regarding the fisheries policy has not been very effective, with the fishermen not accepting the system, leading to a poor enforcement of the fishing quotas. ${ }^{58}$ European institutions, themselves, were sympathetic with the discriminative provisions for the Iberian States in the Act of Accession regarding fisheries and there were some proposals regarding fishing areas. ${ }^{59}$ This rather differentiated treatment to the younger Member States was seen as threatening to the relative stability principle, considering the resentment by the part of the younger Member States. ${ }^{60}$

Another issue was the access Spanish vessels could have to the Portuguese Economic Exclusive Zone, which meant an increased activity of Spanish operators in Portuguese waters. The limitations on the Treaty of the Accession were kept in the following years, with Regulation 1275/94 keeping the same arrangements.

The expiration, in 2002, of the transitional period, lead to the need of a revision, especially considering that the 1995 enlargement led to newer Member States enjoying free access to water, making it politically unacceptable for Spain and Portugal to keep transitional conditions. This led to the revision being done with the adoption of Regulation 1954/2003, known as the "Western Waters Regulation". This Regulation had a particular care for the conservation of sensitive biological areas, especially the atlantic archipelagos ${ }^{61}$, although it led to some controversies.

\footnotetext{
${ }^{56}$ See José Manuel Sobral and Patrícia Rodrigues, "O Fiel Amigo: O Bacalhau e a identidade portuguesa," Etnográfica: Revista do Centro em Rede de Investigação em Antropologia, vol. 17, n. 3 (2013): 629-631.

${ }^{57}$ See Schweiger, "The Evolution of the Common Fisheries Policy: Governance of a Common-Pool Resource in the Context of"... 49 and Yann-Huei Song, "The EC's common fisheries policy in the 1990s," Ocean Development \& International Law, vol. 26, issue 1 (1995): 39.

${ }^{58}$ See the 1992 Report by the Commission to the Council and Parliament On The Application Of the Act of Accession of Spain and Portugal in the Fisheries Sector, SEC/92/ 2340/ final.

${ }^{59}$ See David Steel, "The Role of the European Parliament in the Development of the Common Fisheries Policy," in The Politics of Fishing, ed. Tim Gray (Houndmills: Macmillan Press Ltd, 1998), 42-43.

${ }^{60}$ See Tim S. Gray, "Fishing and Fairness: the Justice of the Common Fisheries Policy," in The Politics of Fishing, ed. Tim Gray (Houndmills: Macmillan Press Ltd, 1998), 239.

${ }^{61}$ See Ernesto Penas Lado, The Common Fisheries Policy: The Quest for Sustainability (Oxford: John Willey \& Sons, Ltd, 2016), 36-40.
} 


\section{The peculiar case of the Portuguese Autonomous Regions in the Common Fisheries Policy}

Being atlantic archipelagos, the Portuguese outermost regions have always had a particular maritime potential, especially with maritime economic activities like fishing, not to mention the strategical value that comes with insularity, being also part of the identity of the regions themselves.

The fishing industry is rather similar to the continental one, being influenced, despite the distance, these archipelagos also contribute with an extensive Economic Exclusive Zone, leading to Portugal having one of the largest Economic Exclusive Zones in the European Union and the world.

The Autonomous regions were affected by the restrictions of the transitory regime of the Portuguese act of Accession. Furthermore Regulations 685/95 and 2027/95 limited fishing areas surrounding the archipelagos, especially in the Azorean waters, while other Member States vessels were particularly restricted especially to fishing tuna.

In any case, the "Western waters Regulation” Regulation 2003/1954 showed a peculiar regime for the Iberian archipelagos, the need for protection of the sensitive biological situation of the waters around the Azores, Madeira and the Canary Islands and the preservation of the local economy of these islands, having regard to their structural, social and economic situation. Limiting certain fishing activities in those waters to vessels registered in the ports of these islands, ${ }^{62}$ is due to the Outermost Region Status these archipelagos have. ${ }^{63}$

This status is based on the principle of proportionality and reflects the special care by the European institutions for the problems associated with remoteness, isolation and geographical hindrances of these islands. ${ }^{64}$ Even fisheries are vulnerable, which is due to the aggregation of the fish, making it easy to find, and the biology of deep-sea fish. ${ }^{65}$

However, in the Azorean case, there was some dissatisfaction with the new regime, considering the previous one was more protective by allowing a complete restriction of fishing vessels, instead of a 100-mile zone like this new Regulation, and ended the restriction for Spanish vessels to fish tuna in parts of the waters in the Azores, which was argued by the Autonomous Region to cause harmful effects on the specific marine environment of the Azores and, consequently, also on the economy of the Azores region. They also argued that the specific protection of the Treaties that comes from the Outermost Region status in the General Court Precedents known as the Região Autónoma dos Açores v. Council was to be respected. The Region's attempt to bring an action for the partial annulment of Regulation No 1954/2003 was unsuccessful, with the Court considering that there were was no successful way of showing that the contested Regulation would harm the environment and fish stocks by virtue of the opening of waters of the Azores to vessels flying the flag of other Member States without limiting their fishing effort or prohibiting their use of trawling. ${ }^{66}$

\footnotetext{
${ }^{62}$ See recital 6 of Regulation 2003/1954.

${ }^{63}$ See $\operatorname{COM}(2002) / 0739 /$ final.

${ }^{64}$ See Carlos Costa Neves, "artigo 349. ${ }^{\circ}$ " in Tratado de Lisboa: Anotado and Comentado, ed. Manuel Lopes Porto e Gonçalo Anastácio (Coimbra: Almedina, 2012), 1223-1225.

${ }^{65}$ See the WWF report on: http://www.seas-at-risk.org/images/pdf/members-news/Joint_SARWWF_Factsheet_on_the_Azores.pdf. For a deeper understanding see the FAO study on: http:// www.fao.org/3/a-i5952e.pdf.

${ }^{66}$ See Paragraph 63 of Região autónoma dos Açores v council case, of 1/07/2008, case T-37/04,
} 


\section{The new challenges for the Autonomous Regions on achieving sustainable development and decentralisation}

Autonomous regions are an unique form of regionalism and decentralisation, with the sustainability principle, like in the Portuguese Constitution, being an important principle of the political-administrative statuses ${ }^{67}$ with the Azorian status recognizing on its Article 3 the development alongside national territory and the European Union and the balanced developed of each island, and Madeira's Status Article 40, recognises the defence of environment and ecological balance as specific competences for regional legislative power.

The European Union has always supported the development of regionalism and regional integration as a way of promoting and enhancing a strategy to coordinate economic policies and improve the prospects for sustainable development. ${ }^{68}$ It can be said that forms of regionalism, decentralisation and autonomy can be a way of promoting sustainable development, considering the local and regional public interest cannot be achieved with the excessive centralization on the national and supranational institutions. ${ }^{69}$

The articulation and interactions between the European, National and Regional forms of governance are based on the subsidiary principle that guarantees, in a complementary way, autonomy to infranational entities, like the Autonomous Regions. ${ }^{70}$

The recent developments of the Common Fisheries Policy have also reflected, as it was mentioned, these phenoms of decentralisation and regionalisation regarding the management of fisheries. The Azorian political-autonomic status is particularly elaborated in this form of decentralisation with its Article 57 stating the legislative power to legislate on matters regarding environmental regional planning, namely protected and classified areas and land and sea conservation and protection zones and Article 53, defining an extensive legislative power on matters of fisheries, sea and marine resources on its territory.

Alongside Regional Governments, the archipelagos fisheries management is aided by the South West Waters Advisory Council, which was created in April 2007 with the Council Decision of 19 July of 2004 to set up the Regional Advisory Councils. ${ }^{71}$

The 2009 Green Paper highlighted the constant problem of over-fishing and over-capacity, as well as the need for an ecological sustainability regarding fisheries and considered the possibility of delegation of specific regional management, leading to an emphasis of the role of Regional Advisory Councils. ${ }^{72}$ Although this paper was rather enigmatic regarding how the delegation and regionalisation would be done, seeming to leave to the Member States to draw their conclusions. ${ }^{73}$ the Report of the Government

ECLI:EU:T:2008:236.

${ }^{67}$ See Gomes Canotilho, “O Princípio da Sustentabilidade como Princípio estruturante”... 7.

${ }^{68}$ See Giulia Piatrengli, "Supporting Regional Integration and Cooperation Worldwide: An Overview of the European Union Approach," in The EU and World Regionalism: The Makability of Regions in the $21^{\text {st }}$ century, ed. Philippe de Lombaerde and Michael Shulz (Surrey: Ashgate, 2009), 11.

${ }^{69}$ See Isabel Celeste M. Fonseca, João Carlos Costa, Rita de Sousa Costa, Rui Castro Vieira and Tiago Sérgio Cabral, "Estudos sobre a organização administrativa das Regiões autónomas...466.

${ }^{70}$ See Maria Luís Duarte, Estudos de Direito da União e das Comunidades Europeias II (Coimbra: Coimbra Editora, 2006), 142.

${ }^{71}$ See the Introduction on the South West Waters Advisory Council, on: http://www.cc-sud.eu/index. $\mathrm{php} / \mathrm{en} /$ contact-swwac?id=50.

${ }^{72}$ See the Green Paper on the Reform of the Common Fisheries Policy, COM(2009)/163/final.

${ }^{73}$ See Symes, "Regionalising the Common Fisheries Policy"... 
of the Azores Autonomous Region about the Green Paper highlighted the Principle of the Sustainable Development and the need for a biogeographic management of fisheries and emphasized the need for decentralisation and subsidiarity and, therefore, the need for regional forms of management as a way of ensuring the sustainable development of the ecosystems on the maritime regions. ${ }^{74}$

The last Common Fisheries Policy reform came with Regulation 1380/2013. Article 18 of this Regulation is focused on regionalisation that allows Member States to submit joint recommendations for achieving the objectives of the relevant Union conservation measures, the multiannual plans or the specific discard plans. Despite the developments, this Article and Regulation are criticised for the fact that the Commission still acts in a "top-down" manner and the fact that regionalisation felt short of what was aspired..$^{75}$

This disappointing development into a regional form of management is particularly impactful for island outermost regions, considering islands tend to have peculiar vulnerabilities often due to their geographical positioning in the world and some oceanic climates, their unique ecosystems which are very vulnerable to external damage and global climate changes that lead to an even increased need for a sustainable development. Island regions have also developed some dynamism in developing the ability to respond to the wide range of influences from within their island borders and from the external pressures created by global issues ${ }^{76}$ and are, therefore, at a better position to work on their local issues.

Autonomic forms of regime like the Portuguese autonomous regions have been shown to be a rather peculiar form of decentralised and regionalist development. and infra-national constitutionalism can enrich the federative developments of the European integration and instigate a a shift towards a regional and multi-level form of governance regarding the Fisheries Policy. This would be the next major step towards the development of the European project, the outermost region status, the principle of subsidiarity and the principle of sustainable development and on the application of a networked constitutional precedents on a supranational and infranational scale that characterizes the post-modern dtate reconfiguration that shapes the very core of the European integration, extending beyond the seas. ${ }^{77}$

\footnotetext{
${ }^{74}$ See the Azorian contribution, on: https://ec.europa.eu/fisheries/sites/fisheries/files/docs/body/ acores_pt.pdf

${ }^{75}$ For a deeper understanding, see Eliasen, Hegland and Raakjær, "Decentralising: The implementation of regionalisation"... 224-232.

${ }^{76}$ See Calbert H. Douglas, "Small Island States and Territories: Sustainable Development Issues and Strategies - Challenges for Changing Islands in a Changing World," Sustainable Development, vol. 14, issue 2 (2006): 75-76.

${ }^{77}$ For a broader understanding about the interconstitutional multi-level federalist development on an European Union of States, Regions and Islands see: Katia Blairon, "The Legislative power of infra-national entities in the European States," Perspectives on Federalism, vol. 4, issue 2 (2012): 217-223., The Committee of The Regions' White Paper on Multilevel Governance of 2009, Patrice WilliamsRiquier, "La Charte Européenne De L' Autonomie Local: Un Instrument Juridique International Pour La Décentralisation," Revue française d'administration publique, 2007/1 (2007): 191-193, Alessandra Silveira, Princípios de Direito da União Europeia: Doutrina e Jurisprudência (Lisbon: Quid Iuris, 2011), 1922. J.J Gomes Canotilho, "Brancosos" e Interconstitucionalidade: Itinerários dos Discursos sobre a Historicidade Constitucional (Coimbra: Almedina, 2012), 265-279.
} 